\title{
Paideusis
}

\section{Constructive Thinking versus Critical Thinking: A Classroom Comparison}

\section{Barbara Thayer-Bacon}

Volume 13, Number 1, 2000

URI: https://id.erudit.org/iderudit/1073019ar

DOI: https://doi.org/10.7202/1073019ar

See table of contents

Publisher(s)

Canadian Philosophy of Education Society

ISSN

0838-4517 (print)

1916-0348 (digital)

Explore this journal

Cite this article

Thayer-Bacon, B. (2000). Constructive Thinking versus Critical Thinking: A Classroom Comparison. Paideusis, 13(1), 21-39.

https://doi.org/10.7202/1073019ar

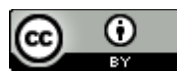

This document is protected by copyright law. Use of the services of Erudit (including reproduction) is subject to its terms and conditions, which can be viewed online.

https://apropos.erudit.org/en/users/policy-on-use/
This article is disseminated and preserved by Érudit.

Érudit is a non-profit inter-university consortium of the Université de Montréal, Université Laval, and the Université du Québec à Montréal. Its mission is to promote and disseminate research.

https://www.erudit.org/en/ 


\section{Constructive Thinking versus Critical Thinking: \\ A classroom comparison'}

\section{Barbara Thayer-Bacon, Ontario Institute for Studies in Education}

\section{Introduction}

I begin by situating myself within my own experiences as a scholar and teacher. As a teacher, I began my teaching career as an elementary Montessori teacher, first in Pennsylvania with children ages 6-10 years for four years, then in California for three years, with children 9-12 years old. When I was an elementary Montessori teacher I noticed something occurring in my classes which triggered questions for me about thinking and learning, about what I call "the inquiring process."

In both states that I taught, I was required to give my students annual performance exams (the Iowa Basics and the California Achievements Tests) to see how they were doing academically compared to other students in their state, as well as in the nation. I noticed that my students uniformly scored 2-3 grade levels above the norm each year, even though my curriculum did not match the public school curriculum for which the tests were designed, and my students did not take any other form of test during the school year. My students' actual ranges of abilities were always wide, and each year I had students who would have been classified as special education students, as well as students in the "average" range, and students who were clearly "gifted and talented." The students with severe learning disabilities were not required to take the achievement tests, but everyone else was. Year after year they all would score high on the tests, and I wondered why everyone seemed to do so well.

I dismissed the possibility that my students did so well on achievement exams because I was a brilliant teacher, for my teaching style was strongly within the Montessori tradition of serving as a guide and resource for my students. My students served as fellow teachers, for our classroom always included mixed age groups, and the students were allowed to, as well as encouraged to work with each other, which is typical of Montessori classrooms. My role was to create a structure where my students could follow their own interests and choose their own work. I was not an active, controlling force in the classroom, but instead worked to create a safe and stimulating environment where my students could work alone or with each other. 1 was available to help with individual questions and needs, as well as to teach small group lessons, and occasional large group lessons. My classroom was the kind of 
room where someone who walked in would likely have a hard time finding me, as the teacher, for I would have my chair pulled up beside one student's desk, or I might be on the rug teaching a new math concept through a Montessori designed concrete material to three students ready to learn long division.

I decided my students must be doing so well on standardized achievement tests which covered material they had not been taught because they were using their critical thinking skills, and just reasoning out what seemed to be the most logical answer. While they were not being taught the specific tested curriculum, they did seem to be having the opportunity to develop the skills they needed to reasonably/ intuitively decide what was the right answer. How were they learning these critical thinking skills? I knew I was not specifically teaching my students critical thinking skills, in terms of teaching them formal or informal logic. I was not even introducing them to something like Matthew Lipman's "philosophy for children" program. ${ }^{2}$ Yet somehow the environment these students were working and studying in was allowing them to learn how to use tools they had available to them, and was helping them to develop the skills they needed to be good inquirers, able to reason through problems and intuitively know how to solve them.

Thus began my own inquiring to try to understand what my students were learning how to do, and how they were learning "it." My dissertation for my Ph.D. in philosophy of education was on critical thinking theory, more specifically: "The Significance of Richard W. Paul's Critical Thinking Theory in Education." ${ }^{3}$ Since writing my dissertation I have continued to explore critical thinking theory, and consider whether or not what other theorists describe as "critical thinking" is what was occurring in my classroom. I have decided "critical thinking" does not seem to describe what my students were learning, almost through osmosis, so well. They were doing more than being rational, logical, good problem solvers. I wish to argue that my students were learning how to constructively think.

Constructive thinking is a term I have adopted from Belenky et al.'s "constructive knowing.," What I like about this term is its emphasis on the idea that thinking is something we actively construct within ourselves, as psychologists such as Vygotsky and Piaget have argued, as well as its emphasis on the idea that thinking is socially constructed, as Berger and Luckman and other sociologists have argued. In his article "The Good, the Bad, and the Ugly: The Many Faces of Constructivism," Denis Phillips likens today's 'constructivism' to a secular religion with many sects and observes that in a very broad and loose sense we are all constructivists, for we all agree that "by and large human knowledge, and the criteria and methods we use in our inquiries, are all constructed." Constructive thinking 
views knowledge as personal and public. As a model for thinking, it stresses the impossibility of separating the self from the object, the knower from the known. This description of thinking allows that there is an interaction between subjectivity and objectivity, and "assigns equal rights to both factors in experience - objective and internal conditions." 7

Using Phillips' classifications to help clarify my constructivist view, I am not using the term, construction, in an individualistic psychological manner, but rather in a more public, sociopolitical way. However, when one takes a sociopolitical perspective, the distinction between the private self and the public comes into question. I am also not using the term, construction, to refer to what goes on inside the mind, as opposed to what is imposed on us from outside, through nature. I use 'construction' to emphasize that knowledge is something human beings create. However, I do not mean that individuals create knowledge by themselves, rather my use of the term is meant to emphasize that this construction is a transactive sociopolitical process with others. Third, my use of the term, construction, is meant to highlight the activity of constructing knowledge, in terms of individual cognition and the social and political process. I am writing a theory of constructive thinking that does not just focus on epistemology, but also includes sociopolitical and educational concerns.

In order to make the argument that my students were learning how to be constructive thinkers, I want to go back to that classroom, and compare what the traditional Euro-western models of critical thinking help us be able to say about the students' inquiring, versus what the constructive thinking model I am developing helps us describe. This approach will allow me to sum up the concerns critical thinkers might have for a constructive thinking model, and it also gives me a method for addressing their concerns. I will conclude with a summation of what I mean by "constructive" thinking. A discussion of what constructive thinking is will be woven throughout the text.

\section{Critical Thinking}

Let's assume I am right in suggesting that the reason my students were doing so well on the tests was because they were learning to be good constructive thinkers (traditionally described as critical thinkers). I have already said I was not specifically teaching my students the skills needed to be constructive thinkers, in terms of any set curriculum, yet I am suggesting they were learning how to be constructive thinkers anyway. How would more traditional critical thinking models describe what was going on in my classroom? What would the past and current models of 
critical thinking help us see? ${ }^{8}$

If an observer walks into my classroom on test-taking day s/he will find around twenty students sitting at individual desks, reading the test questions and filling in bubble sheets with their No.2 pencils. The first thing critical thinking models might point out about my students is that each of them is capable of knowing what is the right answer on the test questions at an individual level. In order to perform well on the test, each student must be able to reason for themselves, without the aid of others. Each individual student uses an elimination process to determine what is the most logical choice for the answer to the question being asked. According to Ennis, s/he must be able to do things such as focus on questions, analyze arguments, define terms, seek clarity, judge sources, and use logical induction and deduction, in order to choose the best answer. ${ }^{9}$

Traditional models of critical thinking describe individuals as having epistemic agency. Individuals are able to solve problems and find solutions on their own, and they do not necessarily need human interaction with others to assure that each of them attain knowledge. For Plato, each of us can tune in to our souls and remember what we each already know, and for Aristotle, each of us can use our reasoning and observation abilities to test out our ideas with our experiences and derive truth. ${ }^{10}$

The traditional critical thinking models also describe my students as reasoners who rely on their minds to be critical thinkers. Their bodies are described as distracters that get in their way and hinder them from being good reasoners. Each of my students, as inquirers, must try to filter out distractions their bodies may be causing for them as they take the test (e.g. they may hear noises in the room, or their own stomachs rumbling due to hunger, etc.). As a teacher, on test-taking day, it is my task to help keep bodily distractions to a minimum so that my students can concentrate and use their critical thinking skills to the best of their abilities. I make sure parents and students are informed of when tests will be administered so students can arrive at school that day on time, rested, and well fed. I insure my students use the restroom facilities and get a drink prior to the test, and I post a sign on my classroom door asking for: "Quiet Please, No Disturbance, Test-taking is in Progress."

If an observer walks into my classroom on a non-test-taking day, what will the traditional critical thinking models draw her or his attention to? What kinds of critical-thinking-type activities are going on? The same twenty students may be working on their own teacher-assigned tasks, or activities they choose for themselves, having completed their assignments. S/he will observe that some students work by themselves, and others in pairs, while still others are in small groups of 
three or four. Maybe s/he will see the entire group having a lesson together. If $s /$ he comes in during a time when they are all silently reading to themselves, or during a group lesson, the observer may perceive the room as quiet and orderly, where students are able to concentrate and further develop their critical thinking skills. However, if s/he comes in when the students work in small groups, while some work by themselves, and others are in pairs, the observer might perceive the classroom as chaotic, and distracting to individuals trying to think critically. The socializing that the students do with each other periodically, throughout each day, will likely be classified as "off-task behavior."

If s/he observes students writing research papers, or working on the computer, participating in a lesson, or reading silently to themselves, the observer might note that the students are learning to ask and answer questions, analyze arguments, define terms, and clarify and challenge positions. With a classroom size of 20 students, and 1 teacher (and a part-time aide) who teaches using a dialogical approach, $\mathrm{s} /$ he will note the students have many opportunities to learn how to critically think and they are encouraged to develop the disposition to be a critical thinker. According to Siegel, the students are being encouraged to develop "certain attitudes, dispositions, habits of mind and character traits," what he calls the critical spirit." They are taught different perspectives on issues. Current events in the world around them are examined, discussed, and related to their own experiences. Their teacher shares her thoughts out loud with them, so logical reasoning is modeled for them, and they are encouraged to do the same. Each student has plenty of opportunities to speak, with others listening to her/his point of view. With the smaller class size and the assistance of a part-time aide, the teaching staff overall succeeds at following through on student assignments, and answering students' questions.

However, an observer will also find in the classroom that some students draw and color in continent maps, some weave on their hand-made looms, some practice a dramatic performance from story-starter suggestion cards, and others create their own design sheets, using geometric shapes to create the designs. The students practice many of these activities without any teacher input. The observer might see these activities as artistic, creative expressions, something fun and playful, or helpful for developing eye-hand co-ordination, but not necessarily connected to learning how to be a better critical thinker. Traditional critical thinking models do not tend to view these artistic-type of activities as useful or necessary in helping students develop their logical, reasoning skills. That these activities are exploratory, selfdiscovery type of activities, without teacher direction or input, further places them in a creative category but not a critical thinking category. 
Many critical theorists may marvel that my students are able to think under my classroom conditions. How is it they are not distracted and interrupted in their concentration? Why are they willing to work on a history or math assignment, when they can also choose to do art? Couldn't I teach them much more in terms of critical thinking skills if I got everyone seated, in their own desks, quietly working on their "academic" assignments? They will advise me to be concerned about what kinds of texts I use, for example, so that I choose ones that are written by credible sources and are based on sound logical analysis. I need to insure I measure what my students know based on forms of assessment that offer my students opportunities to practice their critical thinking skills. I need to continually critique my pedagogical style so that I model good critical thinking and I encourage my students to develop their abilities to reason and learn to value critical thinking too.

By the way, where are my textbooks? I forgot to mention, my classroom does not contain textbooks, except one of each subject for each grade level, which sits over on the self with our other resource materials, such as our dictionaries and encyclopedias. My classroom contains a rich resource library which I continually supplement, and my students all own library cards which they use on our bi-weekly visits to the local library. I spend hours creating concrete materials that my students can manipulate and practice concepts with, before constructively contributing to by creatively creating their own materials. For example, I teach history by using timelines, made from 25 foot or 50 foot long strips of laminated paper or cloth, marked with a ruled line to measure out a stretch of time. The timelines are supplemented with cards containing information and illustrations which can be placed on them. The students manipulate the concrete materials created (or purchased) for their use, and they create their own timelines, to help them master the concepts being taught.

Surprisingly enough, I learned United States history when I had to research the topic, as a teacher, in order to be able to create timeline cards for my students, not when I read about it in my textbooks as a student in school. When I sought a variety of sources and worked to present different perspectives on historical events, I further enhanced my own traditionally described critical thinking skills. However, this was not how history was taught to me as a student. My own students have the opportunity, and challenge, to seek a variety of sources and learn to research topics and events. They bring summaries of what they find to our classroom discussions, and we discuss and debate the various perspectives presented. We do not come to a final conclusion, a definitive statement, but we do learn much about how to analyze arguments, critique sources, and clarify terms, for example. I suggest there is much more that we learn as well, which the traditional critical thinking models do not 
recognize.

The observer in my classroom may wonder how I assess my students' knowledge. I have reported that I did not give my students tests during the school year, so they did not have much opportunity to learn test-taking skills. Two weeks prior to taking the achievement tests, I present them with what I consider "practical life" lessons on how to take tests. They become familiar with answer sheets and how to fill them in. We practice the marks we make on the forms, erasing them, and changing our answers, for example. They learn what it means to start and finish a section within a certain time limit. And they learn about the required conditions for testtaking, in terms of sitting by themselves, with their eyes on their own tests, and no talking allowed, etc. Then they take a sample test, to become more familiar with the format and type of questions asked. Because test taking is a novel experience for them, most of my students enjoy taking the achievement tests.

During the regular school year, when a student finishes an assignment, such as in math, I check the work and note any errors, usually when the work is completed, before the student can move on to another assignment. If there are any errors the student is asked to correct them, and I note if the student needs another lesson, or perhaps the use of a different material. A student is judged to have mastered a math concept when s/he is able to complete an assignment with no errors. In reading, I check a student's reading ability by listening to them individually read to me. I assess their comprehension by asking them questions about what they had read, as well as getting them to write about their understanding, and/or present a report of what they read to their fellow students. I assess them through what I hear, observe, and correct in written form.

A variety of materials are available to afford me the opportunity to teach, and re-teach concepts to students so that if one way does not help, or they need more practice, other ways are available. Students also teach each other lessons, and check each other's work, which helps them further practice concepts. I keep track of students' progress with the use of a note-taking system on a clipboard I carry with me at all times. I note what lessons have been presented to each student, with what materials they are working, or have completed, and how successfully they have completed these. When students achieve mastery of a concept, that is noted, Parent conferences are prepared for by reviewing and fleshing out my records as well as by meeting with each student for their input on their progress. End of year reports are given to parents and students in a narrative form.

Traditional critical thinking models suggest that critical thinking is neutral, unbiased, and objective. My means of assessing students on their abilities may ap- 
pear to many as subjective and of limited value. Our traditional means of assessing students, including the achievement tests we use which initially triggered my questions about critical thinking, tend to emphasize many things about knowledge: that knowledge is a product which can be measured and quantified rather than viewing knowing as a process; that knowledge is separate from us as knowers rather than understanding knowers and knowledge as intimately connected; and that there is one true, right, answer rather than considering knowledge in a more pluralistic, qualitatively relativistic way.

Let me highlight for the reader at this point in the discussion, the criticisms that will likely be made against my transformative project. Critical thinking theorists may worry, does my constructive thinking model lead to a subjective, naturalized, and/or relativistic position? Some may even accuse me of recommending the end to all inquiry, without the use of universal criteria to critique various positions and ideas. They may also suggest that I am logically contradicting myself, insisting that I must rely on a claim of epistemic privilege in order to assert that my theory is better than traditional critical thinking models. Some will wonder, why is it necessary or valuable to embrace a social model of thinking, since pluralism does not necessarily lead to Truth? Why do I want to include artistic qualities in a description of critical thinking? Aren't I confusing critical thinking with creative thinking? Current critical thinking theorists may question my efforts to soften distinctions between empirical evidence and philosophical reasoning, between logic, language, and information, and between a critical thinker's personal, subjective voice and one's expert, reasoning voice.

Now let us look at my classroom from a constructive thinking perspective and see what such an approach allows us to see, that the traditional critical thinking models obscure or marginalize as unimportant, or consider potentially harmful. I will use this section as an opportunity to address the above concerns for a constructive thinking model.

\section{Constructive Thinking}

We walk back into my classroom, prior to test taking day. An observer will notice that the students in this room know each other quite well. Many of these students have been together in this particular school since they were preschoolers. They have been enrolled in classrooms where they spend 3 years with the same teacher, in mixed aged classrooms, so each year they have new students that come into their room, and others that move on, whom they may see again in a few years, when they move on as well to the next age-group. The observer notices that the stu- 
dents know their teacher very well too, as do the students' extended family members, due to the three year cycle. The continuity and longevity of time spent together allows teachers, students, and families, to establish strong relational bonds with each other. ${ }^{12}$

While critical thinking models do not draw attention to the personal relationships between the students and their teachers in the classroom, a constructive thinking model does. Traditional critical thinking models are based on an assumption of individual epistemic agency, however the constructive thinking model is based on a relational ontology, and a relational epistemology. We found above that traditional critical thinking theories may actually consider social interaction in classrooms as noise, and a distraction, "off-task behavior." This is due to their assumption that we each learn individually on our own. I argue that we learn with the aid of others, that learning is a social affair. While I did not realize it at the time that I was teaching this elementary Montessori classroom of students, the structure of my classroom, the design of the curriculum, and my own pedagogical style all support a relational ontology, and a relational epistemology. Let me further explain how by beginning with the students.

The students in the classroom are not treated as isolated individuals, they are viewed as individuals-in-relation-with-others. As described in an earlier book by myself, they are viewed similarly to Dewey's democracy, as a democratic community. ${ }^{13}$ I spend time getting to know my students, and I try to set up ways for them to get to know each other, as well as me, more. We do typical ice breaker activities at the beginning of the school year to help us learn each other's names and more about our backgrounds, and interests. However, I also eat lunch with my students and play with them at recess, and I take the class camping within the first month of the school year, as well as at the end of the school year, as ways to get to know them outside of the traditional classroom setting.

When viewing my classroom through a critical thinking lens, the individual thinker's personal voice was not brought to our attention. If personal voice is discussed in traditional critical thinking theories, as with Paul's weak sense and strong sense critical thinking, the emphasis is on the need to remove one's voice and try to be as objective and neutral as one can in the thinking process. ${ }^{14}$ However, a constructive thinking model recognizes the importance of our personal voices and the impossibility of removing them. This transformed model insists that we examine personal voice issues, for without a personal voice, one cannot hope to contribute to knowing.

An observer viewing my classroom through a constructive thinking lens will 
notice that I continually worry about trying to make my classroom a safe environment, physically and emotionally, so that we who occupy it can feel that we can express ourselves, and others will listen to what we have to say, and appreciate our input, without harming us. We discuss at the beginning of the school year what we need in order to feel safe in our classroom, and then we establish rules of conduct for safety, which we negotiate together. Each of us is responsible for monitoring our own behavior, and we all have the authority to bring it to the class's attention if someone is breaking the safety rules. If we do not like the criteria we have negotiated, maybe we discover something does not work or is not needed, then we always have the option of renegotiating the rules.

Thus, the observer notes that everyone in the classroom has plenty of opportunities to speak, and knows with confidence that others will listen to what is said. This does not mean that we have to agree with each other, many times we do not agree, but it does insure that everyone's voice will be heard, and an effort will be made to hear each of our voices in a caring manner, with generosity and receptivity. The safe environment creates a place where students can afford to take risks, and even fail, and learn from their mistakes. This does not mean that I do not hold high expectations for my students, or that I do not challenge them, for I do. And, they challenge me, and each other, as well.

Having the chance to develop one's personal voice in a safe environment does not mean there will not be questions and problems to solve, with tensions and plenty of opportunities for growth. Life is full of variety and diversity, and so many interesting situations and dilemmas, that growth, as Dewey defined it, will always be a possibility for each student. ${ }^{15}$ That is, as long as students feel that they do in fact have a voice, that others can hear. Unlike the critical thinking models, constructive thinking highlights the necessity of students developing a personal voice in order for them to be knowers.

I did not realize it at the time, but I was helping students develop their personal voices while in my elementary classroom. As my students practiced their skills of communicating and relating to each other, they gained greater insights into their own perspectives of the world and how theirs differed from others. They gained affirmation for their own voices, just by having them generously listened to, and thus gained confidence that they could share their voices with each other. The students learned they might have something to contribute to our knowledge construction. My focus on getting to know my students and trying to create a space where they can develop their own voices is supported by the assumptions that knowers and knowledge cannot be separated, and that as social beings, we learn and 
develop through our interactions with each other.

This brings me to how a dialogical style of teaching supports a relational ontology and epistemology. Most critical thinking theorists also embrace the value of a dialogical approach to teaching. Socrates is often referred to as an excellent model of good teaching, due to his dialogical approach. As we learned in the previous section from a critical thinking perspective, a dialogical approach helps students learn how to ask and answer questions, analyze arguments, define terms, and clarify and challenge positions, for example. A dialogical style of teaching encourages students to develop logical reasoning as well as a critical spirit. However, from a constructive thinking perspective, a dialogical style of teaching does much more, for it helps students learn how to express their personal voices, and it helps students develop their abilities to communicate with and relate to each other.

With a social focus, instead of an individual focus, an observer can begin to see the social interaction that takes place in the classroom as an extremely valuable part of the curriculum, at many levels. The observer notices that my students and I continually practice how to say things to people in ways that make it possible for our words to be received. Daily we learn how to understand someone else's feelings and thoughts by trying to imagine the world from their perspective. We practice how to "tune in" to others' subtle forms of communication, using our intuition to help us. We pay attention to our own emotional feelings and compare these to ones our fellow classmates express. With a dialogical style of teaching, the students are continually encouraged to use their personal voices and all the tools that help them be good constructive thinkers: their emotions, their intuition, their imagination, and their reasoning.

While it might be clear how a dialogical style of teaching encourages critical thinking skills, with a constructive thinking model we begin to realize that dialogical teaching helps students develop their communication skills and relational skills, which are also vitally important in helping students be better thinkers. A dialogical style of teaching helps students develop their communication skills because it provides plenty of opportunities for them to practice communication, and it allows for a variety of ways to teach good communication as well as correct misunderstandings through direct feedback. This style of teaching also makes it possible for students to practice and develop their relational skills, learning how to get along and maintain relationships with others, for relational skills are directly connected to communication skills.

An observer in my classroom will notice that while I may not be aware that I have a formal curriculum devoted to teaching students how to be good constructive 
thinkers, such a curriculum does exist. I teach students how to communicate and relate to each other everyday in our classroom. I must do so because it is impossible to occupy an interactive shared space with 20 other people and not do so, especially if I am trying to create a safe, healthy environment. It certainly is the case that people can occupy a space and not interact with or relate to each other. Students do this all the time, in fact teachers often insist on no communication and no relating. It also is the case that we can experience poor communication, that is destructive to relationships in an interactive environment. Chaos can reign, as can oppression and exclusion, where some students dominate the conversations and relationships and others remain silent, painfully left out. This is why we need safety rules, and why the negotiated rules are an important part of my curriculum.

The observer notes that the classroom structure itself also supports a relational approach to thinking. From the critical thinking description, we already know that the students do not spend all day sitting at individual desks, they have plenty of chances to work with each other. Before, our observer wondered if this environmental structure is conducive or distracting to individual development as critical thinkers. However, now it is clear that the interactive environmental structure further creates opportunities for students to communicate with and relate to each other, thus further enhancing their constructive thinking skills.

The constructive thinking model is not only supported by a relational ontology and epistemology, an assumption that knowers are social beings who cannot be separated from what is known; it is also supported by an assumption that knowers are not disembodied minds, they are people whose minds are directly connected to their bodies, as one bodymind. When our observer walked into the classroom on test taking day, focusing on students as critical thinkers, the observer's attention was drawn to the students' minds. The students' bodies were described as distracters that can cause them to lose their concentration, for example. However, with a constructive thinking focus, our observer is able to view students in a holistic way, as having bodyminds.

Look again at the description of the importance of personal voice, and notice that once we acknowledge the impossibility of getting rid of one's subjective self, bodily functions begin to leak into our description of a constructive thinker. This thinker has emotional feelings, as well as physical sensations. Not only does s/he get hungry and tired, or lose her concentration due to noise in the hallway outside her classroom door, s/he also carries with her into a test taking situation fears of taking tests, or feelings of confidence in her abilities. S/he feels excitement or boredom with the questions $s /$ he is asked to answer. S/he walks into a test-taking situa- 
tion with a stronger or weaker sense of her voice, depending on the context of her life, in school and outside of school, and how others relate to her, and how s/he responds to them. It not only matters what $s /$ he had to eat, or how much sleep $s /$ he had, in terms of how s/he will perform on test taking day. It also matters if $s /$ he had an argument with a family member, or one of her parents just lost their job, or someone remembered to give her a hug on the way out the door.

When we look at the structure of the classroom and my pedagogical style of teaching, we see students moving around the room. We find students talking to each other, maybe whispering in each other's ears, or giggling over a joke. The students in this classroom have permission to use the restroom facilities whenever they need to. They can get a drink, and they can take a snack break in the morning before lunch if they need to, at their own choosing. They can work sitting at a desk or table, or stretched out on the carpet, or lounging on a couch. Before, students moving around the room and talking to each other was considered potentially distracting to critical thinkers. However, with a constructive thinking model, our observer realizes this classroom structure humanely acknowledges that students have bodies, not just minds. Asking students to sit quietly for hours, isolated from interaction with others, and unable to take care of basic physical needs, is a painful request.

Let us look again at what kinds of curricular activities the students do in the classroom. Through a constructive thinking lens, our observer realizes that artistic activities help students learn how to use the very tools they need in order to constructively think, the only tools any of us have at our disposal. These tools are: reason, emotions, intuition, and imagination. Most people recognize artistic endeavors help us develop our intuition, imagination, and emotions. But what about reason? Actors attempting to act out a dramatic scene must rely on all of these tools to help them express characters in a scene in such a way that others can understand what the actors are doing. Painters, dancers, and weavers are no exception as examples either. They use their emotions to help them choose what colors and textures they will use, or with what intensity they will dance, and they use their imagination to envision what they want to represent. They use their intuition to help them decide how to represent "it," and their reason is needed to plan out the execution of the artistic expression.

If we are able to recognize reason is an important tool in artistic expression, then we should be able to also recognize the emotions, intuition, and imagination are valuable tools to help us constructively think. This topic on the tools we use to constructively think is worthy of its own paper. Suffice it to say, for now, that a constructive thinking model helps our observer view the artistic activities students par- 
ticipate in as a valuable and important part of the curriculum. These activities are not "tag-ons" just for fun, though they certainly are fun! They not only breathe life into the curriculum, they help students become better constructive thinkers.

The assessment style I described above, was judged from a critical thinking perspective to be potentially too subjective and relativistic. Our observer noted that critical thinking was used to assess students' mastery of concepts and skills being taught. It can even be noted that I apply universal standards to all of my students, in terms of judging their mastery of concepts based on the number of errors the students make. However, I was judged to be subjective in applying those standards, rather than attempting to be neutral and objective. Therefore, the description of my classroom from a critical thinking lens ended with fears of relativism.

How does my assessment style look from a constructive thinking perspective? Our observer will note that there is a variety of forms of assessment going on, so it is less likely that certain students in the classroom are discriminated against, if a form of assessment does not favor their styles of learning. Students have opportunities to demonstrate to their teacher what they know by choosing a more favorable form. The observer also notes that the individualized forms of assessment used offer me a great deal of diagnostic information, in terms of helping me know what the students' weaknesses and strengths are, and helping me find other ways to address the students' needs. These assessment tools, such as observing the students and checking their work, help me know when to administer a test type of assessment, which is when students have already demonstrated a high success rate. In this way, the test type of assessment is used to confirm mastery, and build students' selfesteem, not diminish their confidence and devalue what they have learned.

Actually, as the head teacher in this classroom, I only administered the standardized achievement tests because I was required by state law to do so. I found that the tests reassured my parents and school administrators that my students were in fact learning what they were supposed to learn, but they did not offer me nearly as accurate or deep level of diagnostic information as my own assessment measures in the classroom offered. And, for my three learning disabled students (one of whom had the highest IQ score in the class, but also the greatest discrepancy between what he was capable of doing, and what he could actually do on a performance based exam), I refused to test them after my first year of experience with achievement tests. The tests only served as a source of frustration and created a sense of failure for them. If the observer looks around my classroom on test day, the next year, s/he will notice there are 17 students in the room taking the test, not 20. 
In regards to the fears of subjectivity, naturalization, and relativity brought out at the end of the last section, in what I have just described it should be already clear how I respond to those charges. The charge of constructive thinking being subjective is something I can only be guilty of if one assumes a subjective/objective distinction, which I do not assume, and which James has already refuted. ${ }^{16}$ In a model which places personal voice as central and necessary to the development of any level of expertise, as a knower, then the distinction between subjectivity and objectivity begins to dissolve. As embedded and embodied individuals, each of us carries our subjectivity with us wherever we go. We cannot shed it like a snake sheds it's skin, or discard it and hang it up in our closet, with our clothes. ${ }^{17}$

Given that the distinction between subjectivity and objectivity is called into serious question, then this sheds a different light on the charge of naturalization. One can only be guilty of naturalization if one assumes it is possible to separate people from what they know. When we begin to understand that we cannot ever get rid of ourselves, our personal voices, our subjectivity, then we begin to realize that it is impossible to not include people in a description of knowledge, for the two cannot be separated. To try to separate the two is a dangerous delusion. Knowers are deeply embedded in knowledge claims. As Harding says, their fingerprints are everywhere. $^{18}$ Thus, the distinction between knowers and knowledge is another dualism that dissolves, and that charge melts away as well. I reject realism (the assumption that knowledge is separate from knowers), and embrace James' radical empiricism and Dewey's naturalism. ${ }^{19}$

Finally, what about the charge of relativism? One may question why I modeled relativism to my students by presenting rules as criteria that are negotiated and renegotiated by us. Do I not risk undermining my own authority as a teacher by allowing students to have a say, and by suggesting there is not one way, one best or truest set of rules? The charge of relativism only makes sense when one assumes there is a distinction between relativism and absolutism. Then absolutism represents what is universally true, and relativism represents what is individually true. However, this false distinction between relativism/ absolutism is based on the above assumption that knowers are divorced from what is known, that the world exists independently of us and what sense we make of it. This distinction has already been shown to be false. Thus, when the dualism between knowers and the known collapses, so does the dualism between relativism and absolutism. What I describe as a qualified relativist position, one based on a pluralistic, fallibilistic perspective, is the only position I argue any of us are justified to take. ${ }^{20}$ Absolutist positions require a leap of faith that cannot be warranted by our reasoning abilities, as fallible, embed- 
ded and embodied social beings. None of us have justified grounds to claim omniscience.

I negotiate with my students over what the rules for safety should be because an assumption of authority would be a false assumption on my part. I am a fallible human being, just as they are. I may have more experiences, more education, and a more expanded, enlarged view as their teacher, but I do not have the Truth. My perspective is limited, as is theirs. I negotiate with my students on criteria to help them understand that ultimately that is all any of us can do. Epistemic agency can only be assured through interaction with others, and that assurance is tenuous, open to further revision. As scientists, or philosophers, we must negotiate with each other in order to come to an agreement of what is, and then pass our efforts on to the next generation for them to debate and discuss further. Individuals can/do make individual contributions to knowledge, but they do not do so as isolated individuals, they are community members. I embrace a fallibilistic view of truths, as I believe most scientists and philosophers currently embrace, though we certainly argue about what Peirce's fallibilism logically entails. ${ }^{21}$ I place the range of fallibilism in Deweyian terms, as warranted assertability. ${ }^{22}$

\section{Conclusion}

Let us conclude with a summation of what I mean by "constructive thinking." Constructive thinking involves the inquiring abilities of culturally embedded, and embodied social people-in-relation-with-others. Constructive thinkers rely on many tools to help them constructively think: reasoning, intuiting, imagining, and emotional tools, for example. These tools do not have a life of their own, they only come to life in the hands of their constructors. The tools are continually in need of critique and retooling, for they are in the hands of fallible, limited, contextual human beings. These tools are used by constructive thinkers to help them develop communication and relational skills, which are vital to social beings. With the use of these tools, and the skills to communicate and relate to others, we all have the possibilities of being constructive thinkers able to contribute to the constructing of knowledge.

What I am recommending with the re-description of critical thinking as constructive thinking is nothing less than a transformation. I am challenging the ideas of universal essences and individual epistemic agency. Instead of a transcendental epistemological perspective that assumes individuals have access to Truth, I am arguing for a pragmatic view of truths as warranted assertability. In challenging the assumption of epistemic privilege, 1 embrace a social model of epistemic communi- 
ties that are multiple, and historically contingent. These communities continually evolve, dissolve, and recombine. Within our epistemic communities, we negotiate the corrigible criteria we use to judge our communal evidence. I answered the charge of relativism by showing the false dichotomy of absolutism/relativism and making the case that all knowledge is provisional and perspectival.

I am questioning the dualistic logic that separates minds from bodies, subjects from objects, and will continue to work to demonstrate the dangerous problems this binary logic creates. I am presenting a relational, holistic, changing view of knowers, as embodied and embedded beings who are not unitary subjects, but rather fragmented, situated, shape shifting subjects, inhabiting bodyminds, while living in relation with others. I challenge the false dichotomy between knowers and what is known, and argue for a dialectical relationship between social beings and ideas that is dynamic, flexible, and reciprocal. Given the transformation I am recommending for critical thinking theory, we realize the importance of addressing cultural influences and political power in theories about thinking.

In this article I hope I have demonstrated that constructive thinking helps us recognize many more of the activities going on in a classroom as forms of inquiry than critical thinking identifies. Once we name these activities as ones that help us constructively think, then we can learn to better appreciate them, understand them, and even encourage them. We begin to see students talking to each other as a way for them to practice their communication and relational skills, and therefore enlarge their views. We realize that students performing drama, music, and art are using their constructive thinking tools just as much as students reading from text books or writing research papers. We begin to understand that a constructive thinking theory offers us ways to more comprehensively explain forms of inquiry in our classrooms.

I offer this description of constructive thinking as a theory that embraces: a social model of epistemic communities, a relational ontology, a relational epistemological theory, and the importance of addressing cultural influences and political power. This constructive thinking theory asks political and ethical questions about traditional Euro-western critical thinking theory, and seeks to show how these questions relate to epistemological assumptions. It is my sincere hope that what I have presented here is a more humble, and inclusive, as well as more empowering theory of how it is we constructively think.

\section{Notes}

1. This article comes from the Preface, Chapter 7, and Chapter 9 of my book, Transforming critical thinking: Thinking constructively (New York: Teachers College Press, 2000).

2. Matthew Lipman, and Ann Sharp, Growing up with philosophy (Philadelphia, PA:

Paideusis 13:1, 2000 
Temple University Press, 1978); Matthew Lipman, Ann Sharp, and F. Oscanyan, Philosophy in the classroom (Philadelphia, PA: Temple University Press, 1980).

3. Author. The significance of Richard W. Paul's critical thinking theory in education (Bloomington, IN: Indiana University, 1991).

4. Mary Belenky, Blithe Clinchy, Nancy Goldberger, Jill Tarule, Women's Ways of Knowing (New York: Basic Books, 1986).

5. Peter L. Berger, and Thomas Luckmann, The Social Construction of Reality: A Treatise in the Sociology of Knowledge (Garden City, NY: Anchor Books, Doubleday \& Company, Inc., 1966).

George Herbert Mead, Mind, Self, and Society: From the Standpoint of a Social Behaviorist, ed. Charles W. Morris (Chicago: University of Chicago Press, 1934).

Jean Piaget, "The Psychogenesis of Knowledge and its Epistemological Significance," in Language and Learning, ed. M. Piatelli-Palmarini (Cambridge, MA: Harvard University Press, 1980).

Lev S. Vygotsky, Thought and Language, trans. by E. Haufmann and G. Vakar (Cambridge, MA: MIT Press, 1962, 1934).

6. Denis C. Phillips, "The Good, the Bad, and the Ugly: The Many Faces of Constructivism," Educational Researcher 24(7)(October 1995), 5-12: 5.

7. John Dewey, Experience and Education (New York: The Macmillan Co., 1938, renewed in 1965). This quote is in reference to Dewey's "principal of interaction," which he later termed 'transaction.'

8. I speak about my classroom in present tense, for ease of discussion, even though I am currently not teaching in an upper elementary Montessori classroom. Instead, I currently teach undergraduate and graduate college students and hopefully I help them learn how to be better constructive thinkers as well. The analogy works surprisingly well for a college classroom setting too.

9. Robert Ennis, "A Taxonomy of Critical Thinking Dispositions and Abilities," in Teaching Thinking Skills: Theory and Practice, eds. Joan Baron and Robert Sternberg (New York: W. H. Freeman, 1987): 9-26.

10. Plato, Republic, trans. and ed. Raymond Larson (Arlington Heights, IL: Harlan Davidson Inc., 1979).

Aristotle, "Nichomachaen Ethics," ed. Steven Cahn, The Philosophical Foundations of Education (New York: Harper \& Row, Publishers, 1970): 107-120. From Aristotle, The Nicomachean Ethics, trans. H. Rackham (Cambridge, MA: Harvard University Press, 1926): 3-619.

Aristotle, The Politics, ed. Steven Cahn, The Philosophical Foundations of Education (New York: Harper \& Row, Publishers, 1970): 121-132. From The Politics of Aristotle, trans. Benjamin Jowett (Oxford: The Clarendon Press, 1885), Vol 1, 213-255.

11. Harvey Siegel, Educating Reason (New York: Routledge, 1988): 39.

12. I am still in contact with many of my students and their families due to these strong bonds. 
13. Author with Charles Bacon, C. S., Philosophy Applied to Education: Nurturing a Democratic Community in the Classroom (Upper Saddle River, $\mathrm{NJ}$ and Columbus, $\mathrm{OH}$ : Merrill Publishing, Prentice-Hall, Inc., 1998).

14. Richard Paul, Critical Thinking: What Every Person Needs in a Rapidly Changing World (Sonoma, CA: Sonoma State University, 1990).

15. John Dewey, Democracy and Education (New York: The Free Press, MacMillan, 1916, 1944, 1966).

Dewey, Experience and education.

16. William James, Pragmatism (Cambridge, MA: Harvard University Press, 1907, 1975b).

17. Author, (Spring, 1995). "Constructive Thinking: Personal Voice, "The Journal of Thought, 30(1), 55-70.

18. Sandra Harding, "Rethinking Standpoint Epistemology: What is "Strong Objectivity"? In Linda Alcoff \& Elizabeth Potter (Eds.), Feminist epistemologies (New York and London: Routledge, 1993): 49-82.

19. William James, Essays in Radical Empirtcism \& A Pluralistic Universe (New York: E. P. Dutton, 1971).

Dewey, J. (1925, 1981). Experience and Nature. In J. Boydston (Ed.). John Dewey: The later works, 1925-1953, Vol. I (pp 1-326). Carbondale: Southem Illinois University Press.

20. It could also be described as a qualified absolutist position, but since terminology such as "non-vulgar absolutism" has already been used by scholars such as Harvey Siegel to describe a weaker form of absolutism, I would rather err on the side of relativism then on the side of absolutism in my description.

Harvey Siegel, Relativism Refuted: A Critique of Contemporary Epistemological Relativism (Dordrecht: D. Reidel Publishing Co., 1987).

21. Charles Sanders Peirce, "How to Make Our Ideas Clear," in Values in a Universe of Chance: Selected Writings of Charles Sanders Peirce (1839-1914), ed. Philip P. Wiener (Garden City, NJ: Doubleday \& Co, Inc., 1958).

22. John Dewey, Logic: The Theory of Inquiry (New York: Henry Holt and Company, Inc., 1938). 